\title{
Determination of $\mathrm{Sn}, \mathrm{Nb}$, and Ta in Tin Concentrates Using Wavelength Dispersive X-Ray Fluorescence Spectrometry
}

\author{
V. Madakkaruppan*, Himadri Basu, Beena Sunilkumar, T.S. Sunilkumar, and Yamuna Singh \\ Atomic Minerals Directorate for Exploration and Research, 1-10-153/156, \\ Begumpet P.O., Hyderabad 500 016, India
}

\section{INTRODUCTION}

Tin (Sn), tantalum (Ta), and niobium $(\mathrm{Nb})$ are extensively used in many modern high-tech industrial applications, such as for superalloys and in the electronics industry $(1,2) . \mathrm{Nb}$ and $\mathrm{Ta}$ have strategic utility in the aero-space industry (missiles, air-planes, etc.), nuclear technology, and in the development of super-conducting technologies (3). Granite and pegmatites are by and large the common host rocks for both magmatic and hydrothermal tin ore deposits in which the major tin-bearing mineral is cassiterite $\left(\mathrm{SnO}_{2}\right)$. Varying contents of $\mathrm{Nb}$ and $\mathrm{Ta}$ (up to $10 \mathrm{wt} . \%$ of $\mathrm{Nb}_{2} \mathrm{O}_{5}$ and $\mathrm{Ta}_{2} \mathrm{O}_{5}$ ) generally reported from such ores can be effectively recovered as by-products $(4,5)$. Sub-microscopic inclusions (exsolved phases) of columbitetantalite within cassiterite mainly account for the Nb-Ta content in tin ore. Other $\mathrm{Nb}$-Ta oxide minerals found associated in minor amounts with cassiterite-bearing ores are tapiolite, wodginite, ixiolite, and pyrochlore (6).

Systematic and rapid analysis of $\mathrm{Sn}, \mathrm{Nb}$, and $\mathrm{Ta}$ in such ores and their panned concentrates/beneficiation products are routinely required for ore-grade monitoring and for regulating process parameters for optimum recovery. Several techniques are employed for the determination of $\mathrm{Sn}, \mathrm{Nb}$, and $\mathrm{Ta}$ such as gravimetry (7), UV-Vis spectrophotometry (8), and inductively coupled plasma optical emission spectrometry (ICP-OES) (9). How-

Corresponding autbor.

E-mail: vmdakkaruppan.amd@gov.in

E-mai: karuppanmv@gmail.com

Tel: +919032881570

\begin{abstract}
An analytical methodology has been developed for the quantification of tin, niobium, and tantalum in tin concentrate samples using wavelength dispersive X-ray fluorescence spectrometry (WDXRFS). A series of synthetic standards were prepared by blending variable but precisely weighed quantities of Specpure ${ }^{\circledR}$ oxides of $\mathrm{Sn}, \mathrm{Nb}, \mathrm{Ta}, \mathrm{Fe}$, and $\mathrm{Mn}$ to obtain a mixture of $\mathrm{SnO}_{2}$ and stoichiometric composition of columbite-tantalite [ $\left(\mathrm{Fe}_{0.8} \mathrm{Mn}_{0.2}\right)$ $\left.(\mathrm{Nb}, \mathrm{Ta})_{2} \mathrm{O}_{6}\right]$. The analytical data obtained by application of this method to tin concentrate samples were compared with those obtained by ICP-OES, and the experimental results are in good agreement.
\end{abstract}

ever, analysis of tin concentrates containing variable quantities of $\mathrm{SnO}_{2}, \mathrm{Nb}_{2} \mathrm{O}_{5}$, and $\mathrm{Ta}_{2} \mathrm{O}_{5}$ by conventional wet chemical techniques is often laborious and involves multiple steps essentially due to the refractory nature of the minerals involved $(7,10,11)$. In this context, the suitability of wavelength dispersive X-ray fluorescence spectrometry (WDXRFS) as a cost-effective, rapid, and eco-friendly technique for the analysis of tin concentrates (>60 wt.\%) containing up to 15 wt. $\%$ of $\mathrm{Nb}_{2} \mathrm{O}_{5}$ and 25 wt. $\% \mathrm{Ta}_{2} \mathrm{O}_{5}$ has been examined, and the method developed is presented here.

\section{EXPERIMENTAL}

\section{Instrumentation}

The XRF measurements were performed on a sequential wave- length dispersive X-ray fluorescence spectrometer (MagiX PRO: PW 2440, PANalytical, The Netherlands), equipped with an end-window Rhanode having a rated capacity of $4 \mathrm{~kW}(66 \mathrm{kV} / 125 \mathrm{~mA})$. The spectrometer consists of two primary collimators (150 and $300 \mu \mathrm{m}$ ), five analyzing crystals (PX 1, PE 002, Ge 111, LiF 200, and LiF 220) with a wide range of $2 d$ spacings, and four detectors (Gas Flow Proportional Counter, Scintillation Counter, Xe-sealed and Duplex detector). The spectrometer was interfaced to a personal computer with the SuperQ software from PANalytical. The instrumental operating conditions are listed in Table I.

\section{Sample Preparation}

The unknown samples were ground to about $45 \mu \mathrm{m}$ size using a jaw crusher/pestle and mortar, followed by high speed impact and swing mills. A smaller representative volume of the homogenized powder of each sample was obtained by coning and quartering. The representative powdered samples/standards of $1 \mathrm{~g}$ were weighed and spread uniformly over a $20 \mathrm{~g}$ boric acid bed in a cylindrical sample die, and finally pelletized in a semi-automatic pelletizer at a pressure of $20,000 \mathrm{~kg} / \mathrm{cm}^{2}$, resulting in a solid pellet of $41 \mathrm{~mm}$ in diameter.

\section{METHODOLOGY}

\section{Preparation of Analytical Standards}

The WDXRFS technique is a comparative method wherein close matrix matching of certified reference materials (CRMs) are highly essential, and are analyzed along with the samples. Since CRMs con- 
taining the intended range of $\mathrm{Sn}$, $\mathrm{Nb}$, and $\mathrm{Ta}$ are not commercially available, a series of eight synthetic standards were prepared by blending variable but precisely weighed quantities of Specpure ${ }^{\circledR}$ oxides of $\mathrm{Sn}, \mathrm{Nb}, \mathrm{Ta}, \mathrm{Fe}$, and $\mathrm{Mn}$. For this purpose, a synthetic mixture of columbite-tantalite of stoichiometric composition of $\left[\left(\mathrm{Fe}_{0.8} \mathrm{Mn}_{0.2}\right)\right.$ $\left.(\mathrm{Nb}, \mathrm{Ta})_{2} \mathrm{O}_{6}\right]$ (12) was initially prepared and mixed with a pure $\mathrm{SnO}_{2}$ base in varying carefully measured proportions. The standard addition and dilution approach was adopted for mixing the oxides. The blended products were further ground in an agate mortar over 30 minutes for homogenization at the particle size of about $45 \mu \mathrm{m}$. The pressed pellet sample preparation method was adopted for WDXRFS analysis. The calculated values of the synthetically prepared standards are given in Table II.

\section{Calibration and Application}

The X-ray fluorescence spectral intensity data on analytical standards obtained from the peaks of characteristic radiations and backgrounds were processed using the SuperQ analytical software (M/s PANalytical Ltd., The Netherlands) using linear regression of the net intensities versus concentrations. The matrix effects were corrected using empirical coefficients, more specifically alphas, based on count rate. The SuperQ analytical software facilitates data conversion, least-squares linear regression analysis (LSLRA), and statistical evaluation. Calibrations relating either to background corrected net count rates or peak count rates to element concentrations in the analytical standards are derived by LSLRA as per regression equation (Eq. 1).

$$
y=m x+c
$$

(Eq. 1)

TABLE I

Instrumental Parameters for the Determination of Sn, Nb, Ta, Fe, and Mn by WDXRFS

\begin{tabular}{lccccc}
\hline Parameters & $\mathrm{Sn}$ & $\mathrm{Nb}$ & $\mathrm{Ta}$ & $\mathrm{Fe}$ & $\mathrm{Mn}$ \\
\hline Line & $\mathrm{K} \alpha$ & $\mathrm{K} \alpha$ & $\mathrm{L} \beta$ & $\mathrm{K} \alpha$ & $\mathrm{K} \alpha$ \\
Potential $(\mathrm{kV})$ & 60 & 40 & 40 & 50 & 50 \\
Current $(\mathrm{mA})$ & 16 & 20 & 20 & 40 & 40 \\
Collimator $(\mu \mathrm{m})$ & 150 & 150 & 150 & 150 & 300 \\
Crystal & $\mathrm{LiF} 220$ & $\mathrm{LiF} 220$ & $\mathrm{LiF} 220$ & $\mathrm{LiF} 200$ & $\mathrm{LiF} 200$ \\
Angle $(2 \Theta)$ & 19.8556 & 30.3904 & 55.5052 & 57.5010 & 62.9660 \\
Detector & Scintillation & Scintillation & Scintillation & Duplex & Duplex \\
\multicolumn{1}{l}{ Time (seconds) } & 20 & 30 & 30 & 20 & 20 \\
\hline
\end{tabular}

TABLE II

Calculated Values of Synthetically Prepared Standards

\begin{tabular}{cccccc}
\hline Standard No. & $\begin{array}{c}\mathrm{SnO}_{2} \\
(\text { wt.\%) }\end{array}$ & $\begin{array}{c}\mathrm{Nb}_{2} \mathrm{O}_{5} \\
(\text { wt.\%) }\end{array}$ & $\begin{array}{c}\mathrm{Ta}_{2} \mathrm{O}_{5} \\
(\text { wt.\%) }\end{array}$ & $\begin{array}{c}\mathrm{Fe}_{2} \mathrm{O}_{3}(\mathrm{~T}) \\
(\text { wt.\%) }\end{array}$ & $\begin{array}{c}\mathrm{MnO}_{2} \\
(\text { wt.\%) }\end{array}$ \\
\hline Syn-1 & 50.00 & 15.27 & 25.39 & 7.34 & 2.00 \\
Syn-2 & 57.00 & 13.13 & 21.84 & 6.31 & 1.72 \\
Syn-3 & 64.00 & 11.00 & 18.28 & 5.28 & 1.44 \\
Syn-4 & 75.00 & 7.64 & 12.70 & 3.67 & 1.00 \\
Syn-5 & 81.00 & 5.80 & 9.65 & 2.79 & 0.76 \\
Syn-6 & 87.50 & 3.82 & 6.35 & 1.83 & 0.50 \\
Syn-7 & 93.75 & 1.91 & 3.17 & 0.92 & 0.25 \\
Syn-8 & 96.88 & 0.95 & 1.59 & 0.46 & 0.12 \\
\hline
\end{tabular}




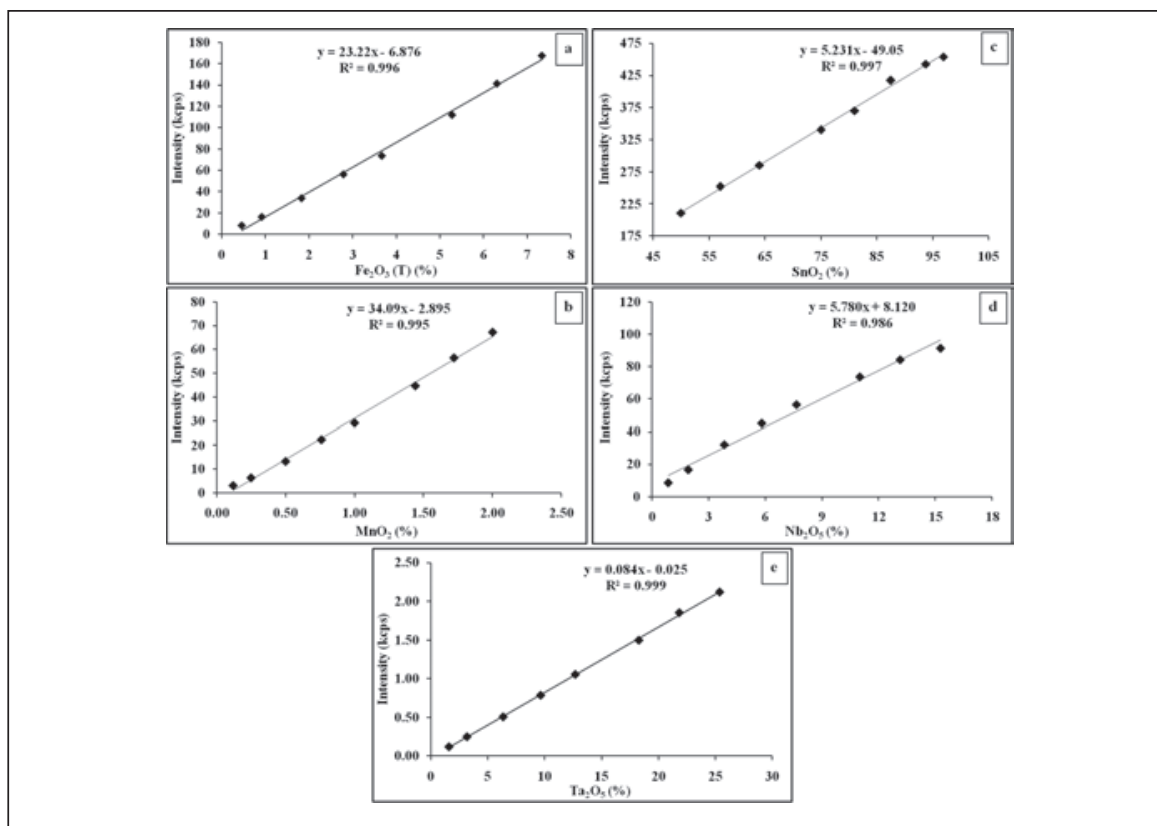

Fig. 1. Calibration curves for (a) $\mathrm{SnO}_{2}$, (b) $\mathrm{Nb}_{2} \mathrm{O}_{5}$, (c) $\mathrm{Ta}_{2} \mathrm{O}_{5}$, (d) $\mathrm{Fe}_{2} \mathrm{O}_{3}$ (T), and (e) $\mathrm{MnO}_{2}$ analysis.

(Syn-1, Syn-4, and Syn-7). In order to evaluate precision, triplicate pellets of each standard were prepared and six measurements for each pellet were carried out. The experimental fluorescent intensities were interpolated in the calibration curve for their determination. The precision was evaluated in terms of relative standard deviation (\% RSD), and accuracy in terms of percent-

TABLE III Spectral Line Interferences on $\mathrm{Sn}, \mathrm{Nb}$, and Ta by WDXRFS

\begin{tabular}{clcc}
\hline $\begin{array}{c}\text { Ele- } \\
\text { ment }\end{array}$ & Line & $\begin{array}{c}\text { Angle } \\
2(\Theta)\end{array}$ & $\begin{array}{c}\text { Relative } \\
\text { Intensity } \\
(\%)\end{array}$ \\
\hline Sn & SnK $\alpha 1$ & 19.8382 & 100 \\
& AgK $\beta 2$ & 19.6908 & 5 \\
Nb & NbK $\alpha 1$ & 30.3744 & 100 \\
& UL $\beta 2$ & 30.7297 & 23.6 \\
Ta & TaL $\beta 1$ & 55.5468 & 57.81 \\
& HfL $\beta \beta 2$ & 55.5286 & 20.48 \\
Fe & FeK $\alpha 1$ & 57.4636 & 100 \\
& ThL $\alpha 2$ & 57.4603 & 11.41 \\
Mn & MnK $\alpha 1$ & 62.9158 & 100 \\
& 3AmL $\beta 2$ & 62.9869 & 23.6 \\
\hline
\end{tabular}

age relative error (\% RE), and standard error (En).

The relative standard deviation (\%RSD; $n=6$ ) of analysis on the synthetically prepared standards by the newly developed WDXRFS method was $0.07-0.17 \%$ for $\mathrm{SnO}_{2}$, $0.20-0.43 \%$ for $\mathrm{Nb}_{2} \mathrm{O}_{5}, 0.68-2.35 \%$ for $\mathrm{Ta}_{2} \mathrm{O}_{5}, 0.16-0.89 \%$ for $\mathrm{Fe}_{2} \mathrm{O}_{3}(\mathrm{~T})$, and $<0.01-0.41 \%$ for $\mathrm{MnO}_{2}$. The error of the analysis by WDXRFS technique was found to be $\pm 0.79-2.56 \%$ for $\mathrm{SnO}_{2}$, $\pm<0.01-0.77 \%$ for $\mathrm{Nb}_{2} \mathrm{O}_{5}$, $\mathrm{n}$ : number of determinations.

SD: standard deviation.

RSD: relative standard deviation. $\pm 0.39-1.14 \%$ for $\mathrm{Ta}_{2} \mathrm{O}_{5}$, $\pm 0.50-2.17 \%$ for $\mathrm{Fe}_{2} \mathrm{O}_{3}(\mathrm{~T})$, and $\pm<0.01-1.00 \%$ for $\mathrm{MnO}_{2}$ (Tables IV-VI).

The limit of detection (LOD) of $\mathrm{SnO}_{2}, \mathrm{Nb}_{2} \mathrm{O}_{5}, \mathrm{Ta}_{2} \mathrm{O}_{5}, \mathrm{Fe}_{2} \mathrm{O}_{3}(\mathrm{~T})$, and $\mathrm{MnO}_{2}$ concentration was at 95 percent confident level and can be calculated using the following equation:

$$
\text { LOD }-\frac{3}{m} \sqrt{\mathrm{I}_{\mathrm{B}} / \mathrm{T}_{\mathrm{B}}}
$$

where $\mathrm{m}=$ net counts per second per parts per million ( $\mathrm{ppm}$ ), $\mathrm{I}_{\mathrm{B}}=$ counts per second of the background and $T_{B}=$ counting time for the background measurement. The lower limits of determination (LOD) were determined and found to be $0.007 \mathrm{wt} . \%$ for $\mathrm{SnO}_{2}$ and 0.020 wt.\% for $\mathrm{Nb}_{2} \mathrm{O}_{5}, 0.20$ wt.\% for $\mathrm{Ta}_{2} \mathrm{O}_{5}, 0.02 \mathrm{wt} \%$ for $\mathrm{Fe}_{2} \mathrm{O}_{3}(\mathrm{~T})$, and $0.050 \mathrm{wt} . \%$ for $\mathrm{MnO}_{2}$.

\section{Application to Nb-Ta Bearing Tin Ore Samples}

In order to evaluate the quality of the WDXRFS analysis of the NbTa bearing tin ore samples, three unknown samples were characterized for $\mathrm{SnO}_{2}, \mathrm{Nb}_{2} \mathrm{O}_{5}, \mathrm{Ta}_{2} \mathrm{O}_{5}$, $\mathrm{Fe}_{2} \mathrm{O}_{3}(\mathrm{~T})$, and $\mathrm{MnO}_{2}$ using the present method, and an alternative method based on ICP-OES determination. The data obtained by WDXRFS were found to be in good agreement with those obtained by ICP-OES (Table VII), thus confirm-

TABLE IV

Accuracy and Precision Using Synthetic Standard (Syn-1) by WDXRFS

\begin{tabular}{lccccc}
\hline Element & $\begin{array}{c}\text { Assigned } \\
\text { Values }\end{array}$ & Mean & SD & RSD & $\begin{array}{c}\text { Uncertainty } \\
\text { of the } \\
\text { Analysis } \\
(\%)\end{array}$ \\
\hline $\mathrm{SnO}_{2}$ & 50.00 & 49.07 & 0.08 & 0.17 & \pm 1.87 \\
$\mathrm{Nb}_{2} \mathrm{O}_{5}$ & 15.27 & 15.29 & 0.03 & 0.20 & \pm 0.12 \\
$\mathrm{Ta}_{2} \mathrm{O}_{5}$ & 25.39 & 25.68 & 0.17 & 0.68 & \pm 1.14 \\
$\mathrm{Fe}_{2} \mathrm{O}_{3}(\mathrm{~T})$ & 7.34 & 7.38 & 0.01 & 0.16 & \pm 0.50 \\
$\mathrm{MnO}_{2}$ & 2.00 & 1.99 & $<0.01$ & 0.26 & \pm 0.67 \\
\hline
\end{tabular}


TABLE V

Accuracy and Precision Using Synthetic Standard (Syn-4) by WDXRFS

\begin{tabular}{lccccc}
\hline $\begin{array}{l}\text { Ele- } \\
\text { ment }\end{array}$ & $\begin{array}{c}\text { Assigned } \\
\text { Values }\end{array}$ & Mean & SD & RSD & $\begin{array}{c}\text { Uncertainty } \\
\text { of the } \\
\text { Analysis } \\
(\%)\end{array}$ \\
\hline $\mathrm{SnO}_{2}$ & 75.00 & 74.41 & 0.06 & 0.08 & \pm 0.79 \\
$\mathrm{Nb}_{2} \mathrm{O}_{5}$ & 7.64 & 7.61 & 0.02 & 0.21 & \pm 0.77 \\
$\mathrm{Ta}_{2} \mathrm{O}_{5}$ & 12.70 & 12.65 & 0.01 & 0.80 & \pm 0.39 \\
$\mathrm{Fe}^{2} \mathrm{O}_{3}(\mathrm{~T})$ & 3.67 & 3.64 & 0.01 & 0.21 & \pm 0.82 \\
$\mathrm{MnO}_{2}$ & 1.00 & 0.99 & $<0.01$ & 0.41 & \pm 1.00 \\
\hline
\end{tabular}

n: number of determination, SD: standard deviation, RSD: relative standard deviation.

TABLE VI

Accuracy and Precision Using Synthetic Standard (Syn-8) by WDXRFS

\begin{tabular}{lcclcc}
\hline $\begin{array}{c}\text { Ele- } \\
\text { ment }\end{array}$ & $\begin{array}{c}\text { Assigned } \\
\text { Values } \\
(\text { wt.\%) }\end{array}$ & $\begin{array}{c}\text { Mean } \\
(\mathrm{n}=6)\end{array}$ & $\mathrm{SD}$ & $\begin{array}{c}\text { RSD } \\
(\%)\end{array}$ & $\begin{array}{c}\text { Uncertainty } \\
\text { of the } \\
\text { Analysis } \\
(\%)\end{array}$ \\
\hline $\mathrm{SnO}_{2}$ & 96.88 & 94.40 & 0.07 & 0.07 & \pm 2.56 \\
$\mathrm{Nb}_{2} \mathrm{O}_{5}$ & 0.95 & 0.95 & $<0.01$ & 0.43 & $<0.01$ \\
$\mathrm{Ta}_{2} \mathrm{O}_{5}$ & 1.59 & 1.58 & 0.04 & 2.35 & \pm 0.63 \\
$\mathrm{Fe}_{2} \mathrm{O}_{3}(\mathrm{~T})$ & 0.46 & 0.47 & $<0.01$ & 0.87 & \pm 2.17 \\
$\mathrm{MnO}_{2}$ & 0.12 & 0.12 & $<0.01$ & $<0.01$ & $<0.01$ \\
\hline
\end{tabular}

$\mathrm{n}$ : number of determination, SD: standard deviation, RSD: relative standard deviation.

TABLE VII

Comparison of Analytical Results by WDXRFS and ICP-OES

\begin{tabular}{|c|c|c|c|c|c|c|}
\hline \multirow{2}{*}{$\begin{array}{l}\text { Oxides } \\
\mathrm{SnO}_{2}\end{array}$} & \multicolumn{2}{|c|}{$\begin{array}{c}\text { Sample } 1 \\
\text { WDXRFS ICP-OES } \\
\text { (wt.\%) }\end{array}$} & \multicolumn{2}{|c|}{$\begin{array}{c}\text { Sample } 2 \\
\text { WDXRFS ICP-OES } \\
\text { (wt.\%) }\end{array}$} & \multicolumn{2}{|c|}{$\begin{array}{c}\text { Sample } 3 \\
\text { WDXRFS ICP-OES } \\
\text { (wt.\%) }\end{array}$} \\
\hline & 65.65 & 65.00 & 66.63 & 66.53 & 66.77 & 64.50 \\
\hline $\mathrm{Nb}_{2} \mathrm{O}_{5}$ & 4.42 & 4.40 & 4.70 & 4.10 & 4.74 & 4.10 \\
\hline $\mathrm{Ta}_{2} \mathrm{O}_{5}$ & 7.60 & 7.30 & 7.37 & 6.80 & 7.42 & 6.90 \\
\hline $\mathrm{Fe}_{2} \mathrm{O}_{3}(\mathrm{~T})$ & 10.97 & 8.69 & 10.08 & 9.30 & 9.66 & 9.55 \\
\hline $\mathrm{MnO}$ & 1.45 & 1.20 & 1.66 & 1.43 & 1.59 & 1.43 \\
\hline
\end{tabular}

ing the accuracy of the results obtained by the WDXRFS method.

\section{CONCLUSION}

An analytical methodology was developed for the quantification of tin, niobium, and tantalum in tin concentrate samples using wavelength dispersive X-ray fluorescence spectrometry (WDXRFS). A series of synthetic standards were prepared by blending variable but precisely weighed quantities of Specpure $^{\circledR}$ oxides of $\mathrm{Sn}, \mathrm{Nb}, \mathrm{Ta}, \mathrm{Fe}$, and Mn to obtain a mixture of $\mathrm{SnO}_{2}$ and

\section{Atomic Spectroscopy \\ Vol. 39(2), March/April 2018}

Joshi, Additional Director (R\&D), Atomic Minerals Directorate for Exploration and Research, for their constant encouragement and kind permission for publishing this research article.

Received September 5, 2017.

\section{REFERENCES}

1. M. Dimitrov, T. Tsoncheva, S. Shao, and R. Kohn, Appl. Catalysis B 94(1-2), 158 (2010).

2. Y. Han, X. Wu, Y. Ma, L. Gong, F. $\mathrm{Qu}$, and H. Fan, Crystal Engineering Community 13, 3506 (2011).

3. C.K. Gupta and A.K. Suri, Extractive Metallurgy of Niobium, CRC Press, USA (1994).

4. W-C. Gao, J-K. Wen, B. Wu, and H. Shang, Rare Metals 33(6), 754 (2014).

5. F. Melcher, T. Graupner, H.E. Gäbler, M. Sitnikova, F.H. Kunst, T. Oberthür, A. Gerdes, and S. Dewaele, Ore Geology Reviews 64, 667 (2015).

6. P. Cerny, B.E. Goad, F.C. Hawthorne, and R. Chapman, American Mineralogist 71, 501 (1986).

7. I.M. Gibalo, Analytical Chemistry of Niobium and Tantalum, 2, Ann Arbor/Humphrey Science Publishers, London, (1970).

8. G. Charlot, Les Methodes de la Chimie Analytique. Massonet Cie, Paris, France, 814 (1961).

9. P. Roychowdhury, N.K. Roy, and A.K. Das, At. Spectrosc. 16, 104 (1995).

10. T. Arai, The Rigaku Journal 21(2), 26 (2004).

11. D. Wegrzynek, A. Markowicz, E. Chinea-Cano, and S. Bamford, $\mathrm{X}$-ray spectrometry, DOI: 10.1002/xrs.639 (2003).

12. T.S. Erctt, M.A. Wise, and P. Cerny, American Mineralogist 80, 613 (1995).

13. E.P. Bertin, Principles and practice of X-ray Spectrometric analysis. Plenum Press, New York, 679 (1970).

14. S. Viswanathan, A. Chaki, and Y. Singh, The Indian Mineralogist 44(1), 1 (2010). 